\title{
Fungal Elicitation of Signal Transduction-Related Plant Genes Precedes Mycorrhiza Establishment and Requires the dmi3 Gene in Medicago truncatula
}

\author{
Stéphanie Weidmann, Lisa Sanchez, Julie Descombin, Odile Chatagnier, Silvio Gianinazzi, and \\ Vivienne Gianinazzi-Pearson \\ UMR INRA 1088/CNRS 5184/U. Bourgogne Plante-Microbe-Environnement, INRA-CMSE, BP 86510, 21065 Dijon cedex, \\ France
}

Submitted 20 February 2004. Accepted 3 August 2004.

\begin{abstract}
Suppressive subtractive hybridization and expressed sequence tag sequencing identified 29 plant genes which are upregulated during the appressorium stage of mycorrhiza establishment between Medicago truncatula $\mathrm{J5}\left(\mathrm{Myc}^{+}\right)$and Glomus mosseae. Eleven genes coding plant proteins with predicted functions in signal transduction, transcription, and translation were investigated in more detail for their relation to early events of symbiotic interactions. Expression profiling showed that the genes are activated not only from the appressorium stage up to the fully established symbiosis in the $\mathrm{Myc}^{+}$genotype of $\mathrm{M}$. truncatula, but also when the symbionts are not in direct cell contact, suggesting that diffusible fungal molecules (Myc factors) play a role in the induction of a signal-transduction pathway. Transcript accumulation in roots of a mycorrhiza-defective $\mathrm{Myc}^{-}$dmi3 mutant of $M$. truncatula is not modified by appressorium formation or diffusible fungal molecules, indicating that the signal transduction pathway is required for a successful G. mosseae-M. truncatula interaction leading to symbiosis development. The symbiotic nodulating bacterium Sinorhizobium meliloti does not activate the 11 genes, which supposes early discrimination by plant roots between the microbial symbionts.
\end{abstract}

Additional keywords: signaling pathway.

Terrestrial plants have developed numerous strategies to cope with the diverse biotic and abiotic challenges that they have met with during evolution. One of the most successful strategies is their ability to establish reciprocally beneficial symbiotic relationships with microorganisms (GianinazziPearson 1996), of which the most widespread is represented by arbuscular mycorrhizal (AM) associations between Glomeromycota fungi and root systems (Schüssler et al. 2001; Walker and Trappe 1993). Arbuscular mycorrhizas are instrumental in the survival and fitness of many plant taxa in diverse ecosystems through their function in the efficient exploitation of soil mineral resources and their bioprotective role against a number of common soilborne pathogens (Barea et al. 2002). The development of this type of symbiosis requires significant morphophysiological alterations in both plant and fungal cells that are assumed to be coordinated via a reciprocal exchange of signals (Liu et al. 2003). The colonization of root tissues by an

Corresponding author: V. Gianinazzi-Pearson; E-mail: Vivienne.GianinazziPearson@epoisses.inra.fr
AM fungus follows a well-defined series of morphogenetic events which begin with hyphal branching and formation of an appressorium at the root surface (Giovannetti et al. 1994). These culminate in the intense proliferation of mycelium within the cortical parenchyma, where differentiation of specialized, highly branched, arbuscules is induced within host cells (Gianinazzi-Pearson 1996).

Little is known of molecular interactions prior to and during initial contact between AM fungi and plant roots, mainly due to difficulties in synchronizing developmental events in the two symbionts in order to dissect gene expression patterns and correlate them with these early stages of the symbiosis. AM fungi show limited development during asymbiotic spore germination. In Glomus mosseae (Nicol. \& Gerd.), this is associated with expression of a GTPase-encoding gene which may be involved in programmed cell death of hyphae in the absence of a host signal (Requena et al. 2002). The perception of specific plant signals by AM fungi is indicated by gene activation in Gigaspora rosea (Nicolson \& Schenck) that is elicited by host root exudates during the developmental switch from spore germination to extensive hyphal branching (Tamasloukht et al. 2003), and by the induction of an $\mathrm{H}^{+}$-ATPase gene GmHA5 in Glomus mosseae upon appressorium formation on host roots (Requena et al. 2003). In this context, there exists evidence that appressoria may form in response to a plant signal endogenous to the root epidermal cell wall (Nagahashi and Douds 1997).

Plant gene expression that has been monitored during the appressorium stage of the AM symbiosis is mainly related to defense responses. Several studies on Medicago truncatula Gaertn. have demonstrated that plant defense genes generally show weak and transient activation in early root interactions with AM fungi (Bonanomi et al. 2001; Harrison 1999). In tobacco, a transient increase in catalase and ascorbate peroxidase activities appeared with the formation of the first appressoria by $G$. mosseae on roots (Blilou et al. 2000), and the expression of one defense-related gene in pea ( $p I 206$ ) was correlated with appressorium formation by this fungus (Ruiz-Lozano et al. 1999). Such activation of plant defense genes during the early stages of mycorrhizal interactions gave first indications for the existence of fungal signal molecules.

More direct evidence that AM fungi can induce a localized gene response to appressorium in host roots has been provided by studies on MtENOD11-driven gusA expression in M. truncatula. Epidermal cells in the immediate vicinity of appressoria formed by Gigaspora spp. show a transient low level of transgene activity which disappears with the appearance of a 
strong gene expression in cells where arbuscules develop (Chabaud et al. 2002). It subsequently was shown that a diffusible AM fungal ("Myc") factor could induce strong MtENOD11-gusA expression, primarily in root cortical tissues without cell contact between the symbionts (Kosuta et al. 2003).

$\mathrm{AM}$ formation and nodulation are commonly controlled by a number of genes in M. truncatula (DMI1, DMI2, and DMI3), pea (sym 8, sym19, and sym9/30), and Lotus japonicus (LjsymRK) (Albrecht et al. 1999; Catoira et al. 2000; Duc et al. 1989; Endre et al. 2002; Gianinazzi-Pearson 1996; Stracke et al. 2002). The genes DMI2 and LjsymRK have been identified as coding a receptor-like kinase (Endre et al. 2002; Stracke et al. 2002). It recently has been reported that the DMI3 gene is highly similar to a calcium- and calmodulin-dependant protein kinase, while the DMII gene codes a novel protein showing low similarity to a ligand-gated cation channel (Ané et al. 2004; Lévy et al. 2004; Mitra et al. 2004). Plants mutated for these genes are unable to establish a functional association with rhizobia and AM fungi ( $\mathrm{Nod}^{-} / \mathrm{Myc}^{-}$phenotypes), but formation of appressoria by the latter does occur on their roots without hyphal penetration (Calantzis et al. 2001; Catoira et al. 2000; Sagan et al. 1995; Wegel et al. 1998). The MtENOD11 gene is activated by the diffusible AM fungal factor in roots of $\mathrm{Myc}^{-} d m i 1, d m i 2$, and $d m i 3$ mutants, suggesting that a $D M I-$ independent signal transduction pathway is involved in this response (Kosuta et al. 2003). However, contact-driven expression of this gene is absent from epidermal root cells of a $\mathrm{Myc}^{-}$ $d m i 2$ mutant associated with appressoria, suggesting that two Myc signals may activate MtENOD11, one that requires contact with the plant and is DMI dependent, and one that does not require contact and is DMI independent. Likewise, we recently have found six other appressorium-induced $M$. truncatula genes that are DMI dependent because they are not activated during initial fungal contact with root cells in a $\mathrm{Myc}^{-}$ dmi3 mutant (Brechenmacher 2003; Brechenmacher et al. 2004).

To further elucidate the molecular dialogue which is implemented during early events leading to AM development, we have identified genes expressed in root systems synchronized for the appressorium stage of interactions between $M$. truncatula and G. mosseae. Studies were focused on pathways potentially related to symbiotic fungal signal perception by $M$. truncatula in $\mathrm{Myc}^{+}$and $\mathrm{Myc}^{-}$genotypes. We present data showing
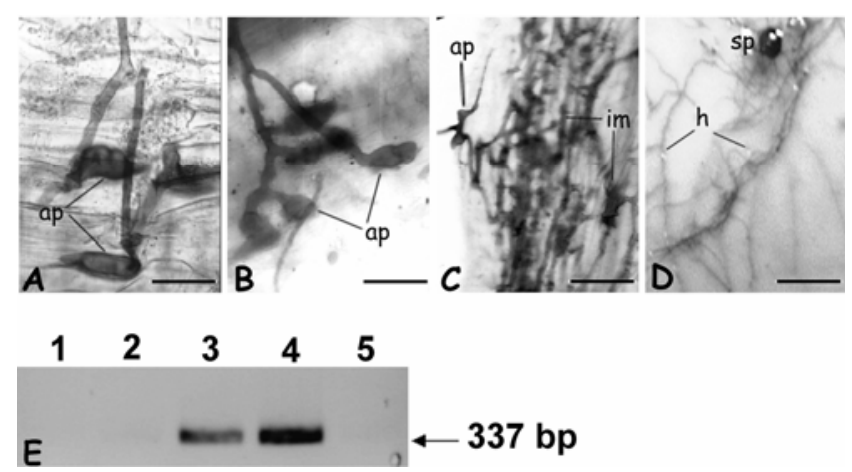

Fig. 1. Medicago truncatula-Glomus mosseae interactions. A, Appressoria (ap) on a root of the $\mathrm{Myc}^{+}$genotype J5 5 days after inoculation (dai). Bar $=25 \mu \mathrm{m}$. B, Appressoria (ap) on a root of the $\mathrm{Myc}^{-}$mutant TRV25 7 dai. Bar $=30 \mu \mathrm{m}$. C, Appressorium (ap) and intraradical mycelium (im) in a mycorrhizal root of the genotype J5 10 dai. Bar $=100 \mu \mathrm{m}$. D, Spore $(\mathrm{sp})$ and hyphal network $(\mathrm{h})$ developed on a membrane after 2 weeks. Bar $=0.4$ $\mathrm{mm}$. E, Reverse-transcription polymerase chain reaction detection of large subunit ribosomal RNA of $G$. mosseae from $M$. truncatula J5 roots grown without inoculation (lane 1), with germinated spores separated by a membrane (lane 2), 5 dai by $G$. mosseae (lane 3 ), and 10 dai by $G$. mosseae (lane 4). The fifth lane corresponds to the water control. that activation of plant genes related to signal transduction and translation prior to and during symbiont cell contact is associated with successful root colonization.

\section{RESULTS}

Microbe development and plant growth.

G. mosseae consistently developed the first appressoria on the root surface of the $M$. truncatula J5 genotype 3 days after inoculation (dai) and reached an average of 4.2 appressoria per $\mathrm{cm}$ root 5 dai. Fungal development was slower on roots of the Myc $^{-}$TRV25 mutant and needed 7 dai to reach a similar level of appressorium development (3.7 appressoria/cm of root). Root penetration never was observed after trypan blue coloration in different experiments at these time points in either genotype (Fig. 1A and B). First arbuscules appeared 6 to 7 dai in roots of $M$. truncatula $\mathrm{J} 5$ and the mycorrhizal symbiosis was fully established in M. truncatula J5 plants at 10 dai, with $84 \%$ of the root system colonized and $31 \%$ containing arbuscules (Fig. 1C). At this time, an average of 3.1 appressoria/cm of root had developed. In all cases, no contamination by other microorganisms was observed. Root colonization of $M$. truncatula J5 plants by $S$. meliloti was evaluated as being $2 \times 10^{8}$ bacteria/root system at 4 dai and there was no significant effect of inoculation on root or shoot growth. No nodules had developed at this time.

Shoot fresh biomass of the G. mosseae-inoculated J5 genotype, with (average $30.7 \mathrm{mg}$ ) or without (average $40 \mathrm{mg}$ ) root contact, was significantly $(P<0.0001)$ higher than noninoculated plants ( 22.6 and $30 \mathrm{mg}$, respectively) at 5 dai. Root fresh weights of $M$. truncatula J5 plants 5 dai, with $(32.3 \mathrm{mg})$ or without $(37 \mathrm{mg})$ contact by $G$. mosseae, also were significantly $(P<0.05)$ greater than those of noninoculated control plants (26.2 and $25.7 \mathrm{mg}$, respectively). These effects of $G$. mosseae inoculation on plant growth were not observed for the TRV25 genotype. When the $M$. truncatula J5 genotype plants reached 10 dai, the shoot fresh biomass was significantly $(\mathrm{P}<$ 0.0001 ) different between noninoculated (average $43 \mathrm{mg}$ ) and inoculated (average $45.3 \mathrm{mg}$ ) plants. On the contrary, root fresh weights were not significantly different between treatments at 10 dai by $G$. mosseae.

Identification of appressorium-induced genes and proteins.

The subtractive suppressive hybridization (SSH) library (M. truncatula-G. mosseae early stage [MtGmEs] interaction) of 1,444 clones (average insert size $=570 \mathrm{bp}$ ) was screened with cDNA probes from noninoculated and $G$. mosseae-inoculated $M$. truncatula $\mathrm{J} 5$ roots (5 dai) of plants different from those used to construct the SSH library (average 3.8 appressoria/cm of root). Polymerase chain reaction (PCR) (with primers corresponding to selected expressed sequence tags [ESTs]) on the RNA samples before reverse transcription gave no amplification signals, confirming that there was no contamination by genomic DNA (data not shown). Reverse Northern hybridization signals were normalized using the Mtgapl gene. ESTs corresponding to genes with at least 2.5fold increases in transcript accumulation in three experimental repeats of inoculated compared with control roots were sequence analyzed. Analysis of 900 clones gave 29 genes which consistently were upregulated in $G$. mosseae-inoculated M. truncatula J5 roots (Table 1). Sequences for which no redundancy was detected were designated as MtGmEs and deposited in the EMBL databases (accession numbers AJ621847 to AJ621875). All of these genes presented a basal expression in noninoculated roots and had E values showing significant similarities only to plant genes. The most represented gene categories coded for proteins related to primary 
metabolism $(n=6)$, protein synthesis $(n=7)$, signal transduction $(n=4)$, or unknown functions $(n=5)$ None of these genes previously have been reported to be expressed in mycorrhizal interactions. For the six genes of the primary metabolism category, two corresponded to Arabidopsis thaliana L. Heynh sequences encoding an F1F0-ATPase inhibitor-like protein and a methylenetetrahydrofolate reductase, two to Nicotiana tabacum L. sequences with diacylglycerol acylCoA acyltransferase and an isopentenyl diphosphate isomerase 1 functions, one to a ferredoxin nitrite reductase gene of soybean, and one to a GDP-mannose pyrophosphorylase gene of Solanum tuberosum L. (Table 1). The four ESTs of the signal transduction category matched genes encoding a tomato calcium lipid binding protein, an A. thaliana MAP kinase, a cotton fiber annexin, and an L. japonicus nitrate reductase. In the category of protein synthesis, three matching sequences originated from $A$. thaliana (eukaryotic initiation factor $4 \mathrm{~F}$, $40 \mathrm{~S}$ ribosomal protein $\mathrm{S} 3$, and 60S ribosomal protein L7), two from Castanea sativa Mill. (60S ribosomal protein L18a), one from potato (small nuclear ribonucleoprotein UA1), one from $N$. tabacum (eukaryotic initiation factor 4A), and one from $N$. paniculata L. (elongation factor $1-\alpha$ ).

\section{Gene expression in wild-type $M$. truncatula $\mathbf{J 5}$ and the $\mathrm{Myc}^{-}$dmi3 mutant TRV25.}

Following the above analyses, four genes related to signal transduction (annexin, calcium lipid binding protein, MAP kinase, and nitrate reductase), one to transcription (small nuclear ribonucleoprotein UA1), and six to translation events (two eukaryotic initiation factors, three ribosomal proteins, and one elongation factor 1- $\alpha$ ) were selected for more detailed investigation. Expression profiling was performed by semiquantitative reverse transcription (RT)-PCR (Burleigh 2001) using primers deduced from the EST sequences corresponding to the 11 genes and the number of cycles given in Table 2 . Contrary to Northern analyses, semi-quantitative RT-PCR not only enables specific detection of a gene family member but also is sufficiently sensitive to detect transcripts in limited amounts of tissue like those interacting with appressoria. As above, Mtgapl gene expression was chosen as the reference. Roots from new sets of $G$. mosseae-inoculated and noninoculated $M$. truncatula plants were used. RNA was extracted and checked for the absence of DNA contamination. Representative RT-PCR profiles are shown in Figure 2. Significant activation $(P<0.05)$ was confirmed in roots of the M. truncatula J5 genotype 5 dai by $G$. mosseae from three independent inoculation experiments (average, 4 appressoria/ $\mathrm{cm}$ of root) for all the genes (Fig. 3A). None of the 11 plant genes were significantly upregulated by $G$. mosseae appressorium formation on roots (average, 3.7 appressorium $/ \mathrm{cm}$ of root) of the $M$. truncatula dmi3 mutant 7 dai (Fig. 3B), where the fungus cannot penetrate inside the root tissues. The 11 genes activated in $M$. truncatula roots at the appressorium stage likewise were upregulated at 10 dai when $G$. mosseae had proliferated further along and colonized roots (Fig. 2).

\section{Gene expression prior to fungal-root contact.}

Transcripts of the $M$. truncatula genes related to signal transduction, transcription, and translation also were monitored before contact between root and fungal cells. For this, spores of G. mosseae pregerminated between nitrocellulose membranes were placed on $M$. truncatula roots (J5 genotype or dmi3 mutant) to physically separate fungal and plant tissues but allow diffusion of molecules between them. On average, $50 \%$ of spores germinated in the presence of either plant genotype and produced a ramified hyphal network on the membranes (Fig. 1D). Expression profiling of the $11 \mathrm{M}$. truncatula genes showed that they were significantly upregulated in root sys-

Table 1. Sequence similarities at protein levels for expressed sequence tags of $\geq 2.5$-fold upregulated genes in Medicago truncatula J5 roots 5 days after inoculation with Glomus mosseae

\begin{tabular}{|c|c|c|c|c|}
\hline $\begin{array}{l}\text { MtGmEs } \\
\text { clone }^{\mathrm{a}}\end{array}$ & $\begin{array}{c}\text { Accession } \\
\text { number }\end{array}$ & Matching predicted protein ${ }^{b}$ & $\begin{array}{l}\text { TIGR } M \text {. truncatula } \\
\text { gene index }\end{array}$ & $\begin{array}{c}\text { E value } \\
\text { (Blast } X)\end{array}$ \\
\hline 1 & AJ621848 & Similar to Arabidopsis thaliana chromosome $5-$ A. thaliana & TC77198 & $1.6 \mathrm{e}^{-34}$ \\
\hline 9 & AJ621847 & $\mathrm{Ca}^{2+}$ lipid binding (CLB1) protein-Lycopersicum esculentum & TC78567 & $1.1 \mathrm{e}^{-82}$ \\
\hline 12 & AJ621849 & 40S ribosomal protein S3 (40S RP S3) -A. thaliana & TC85147 & $1.1 \mathrm{e}^{-22}$ \\
\hline 14 & AJ621850 & Diacylglycerol acylCoA acyltransferase-Nicotiana tabacum & BQ148998 & $7.1 \mathrm{e}^{-47}$ \\
\hline 108 & AJ621851 & HMGI/Y protein-Garden pea & TC77788 & $4.6 \mathrm{e}^{-113}$ \\
\hline 133 & AJ621852 & MAP kinase (MAPK) -A. thaliana & TC87038 & $6.3 \mathrm{e}^{-114}$ \\
\hline 160 & AJ621853 & Isopentenyl diphosphate isomerase $1-N$. tabacum & TC77413 & $3.6 \mathrm{e}^{-113}$ \\
\hline 330 & AJ621854 & Annexin-Upland cotton & TC85793 & $1.1 \mathrm{e}^{-78}$ \\
\hline 350 & AJ621855 & F1F0-ATPase inhibitor-like protein-A. thaliana & TC86884 & $9.4 \mathrm{e}^{-92}$ \\
\hline 367 & AJ621856 & 60 ribosomal protein L7 (60S RP L7)-A. thaliana & TC77462 & $8.5 \mathrm{e}^{-24}$ \\
\hline 376 & AJ621857 & Putative pollen germination related protein-Oryza sativa & TC77426 & $3.0 \mathrm{e}^{-89}$ \\
\hline 445 & AJ621858 & Methylene tetrahydrofolate reductase-A. thaliana & TC85756 & $2.3 \mathrm{e}^{-120}$ \\
\hline 457 & AJ621859 & Hs1pro-1 homolog-Pisum sativum & TC76759 & $2.1 \mathrm{e}^{-85}$ \\
\hline 470 & AJ621860 & Ribosomal protein $18 \mathrm{a}-$ Castanea sativa & TC76395 & $6.9 \mathrm{e}^{-38}$ \\
\hline 642 & AJ621861 & Ferredoxin nitrite reductase-soybean & TC77277 & $2.9 \mathrm{e}^{-163}$ \\
\hline 644 & AJ621862 & Weakly similar to receptor-like protein kinase homolog RK20-1-Phaseolus vulgaris & TC85561 & $2.8 \mathrm{e}^{-36}$ \\
\hline 645 & AJ621863 & Eukaryotic initiation factor $4 \mathrm{~F}(\mathrm{eIF} 4 \mathrm{~F})-A$. thaliana & TC86593 & $2.4 \mathrm{e}^{-33}$ \\
\hline 670 & AJ621864 & ADR6-soybean & TC86246 & $2.3 \mathrm{e}^{-67}$ \\
\hline 762 & AJ621865 & $60 \mathrm{~S}$ ribosomal protein $\mathrm{L} 18 \mathrm{a}(60 \mathrm{~S} \mathrm{RP} \mathrm{L} 18 \mathrm{a})-C$. sativa & TC76395 & $1.2 \mathrm{e}^{-31}$ \\
\hline 768 & AJ621866 & Eukaryotic initiation factor 4A (eIF4A)-N. tabacum & TC76958 & $5.6 \mathrm{e}^{-126}$ \\
\hline 770 & AJ621867 & Nitrate reductase (NR)_Lotus japonicus & TC78214 & $8.3 \mathrm{e}^{-87}$ \\
\hline 771 & AJ621868 & Small nuclear ribonucleoprotein UA1 (SnRNP UA1)_Solanum tuberosum & TC78767 & $8.8 \mathrm{e}^{-46}$ \\
\hline 773 & AJ621869 & GDP-mannose pyrophosphorylase-S. tuberosum & TC77044 & $3.7 \mathrm{e}^{-39}$ \\
\hline 774 & AJ621870 & Expansin-Prunus cerasus & TC78682 & $5.4 \mathrm{e}^{-72}$ \\
\hline 775 & AJ621871 & Extensin-like protein $\mathrm{S} 3-M$. sativa & TC78495 & $9.8 \mathrm{e}^{-44}$ \\
\hline 776 & AJ621872 & Cyclin $\mathrm{B}-P$. sativum & AL377325 & $2.4 \mathrm{e}^{-45}$ \\
\hline 777 & AJ621873 & Unnamed protein product-L. esculentum & TC85735 & $1.1 \mathrm{e}^{-44}$ \\
\hline 890 & AJ621874 & Elongation factor-1 alpha $(\mathrm{EF} 1 \alpha)-N$. paniculata & TC85175 & $5.3 \mathrm{e}^{-09}$ \\
\hline 899 & AJ621875 & npp & $\ldots$ & $\ldots$ \\
\hline
\end{tabular}

\footnotetext{
${ }^{\mathrm{a}} \mathrm{MtGmEs}=$ M. truncatula - G. mosseae early stage.
}

${ }^{\mathrm{b}} \mathrm{npp}=$ No predicted protein. 
tems of the $\mathrm{J} 5$ genotype after 5 days in the presence of the fungus, compared with control roots (Fig. 3C), except for one of them (annexin), for which activation was consistently, but not significantly, observed due to some variation between samples. On the contrary, none of the $M$. truncatula genes were upregulated when the fungus was separated from roots of the dmi3 $\mathrm{Myc}^{-}$mutant (Fig. 2D). No hyphal contact with $M$. truncatula roots was ever observed after extensive microscopic examination of root systems stained with trypan blue. This was con-

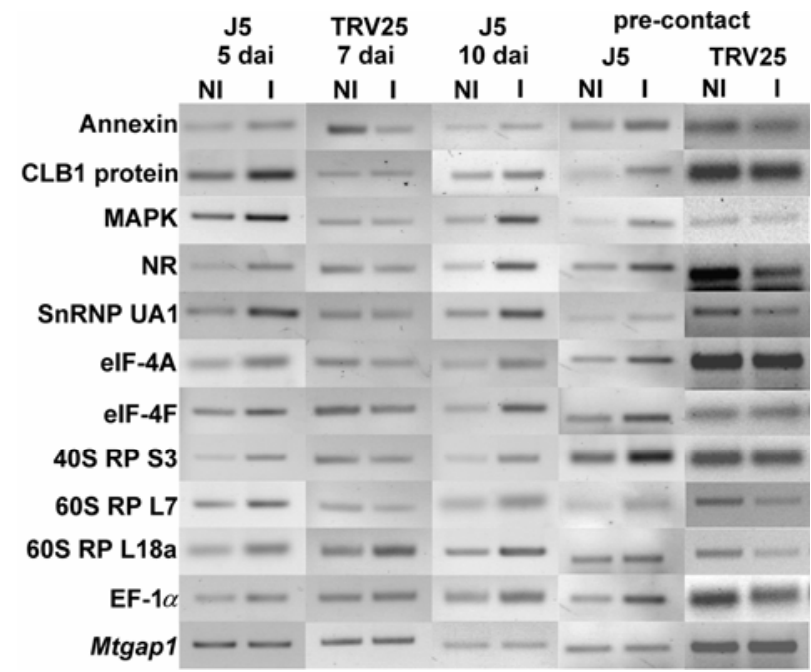

Fig. 2. Representative reverse-transcription polymerase chain reaction profiles for four genes of signal transduction, one of transcription, and six of translation in i) the $\mathrm{Myc}^{+}$Medicago truncatula J5 genotype at 5 and 10 days after inoculation (dai) by Glomus mosseae, ii) the $\mathrm{Myc}^{-} \mathrm{TRV} 25$ genotype 7 dai, and iii) the $\mathrm{Myc}^{+} \mathrm{J} 5$ and $\mathrm{Myc}^{-}$TRV 25 genotypes separated from germinated spores and hyphae of $G$. mosseae roots by a nitrocellulose membrane. NI: noninoculated; I: inoculated. Signal transduction genes: Annexin, CLB1 protein $\left(\mathrm{Ca}^{2+}\right.$ lipid binding protein), MAPK (MAP kinase), NR (nitrate reductase); transcription gene: SnRNP UA1 (small nuclear ribonucleoprotein UA1); translation genes: eIF-4A (eukaryotic initiation factor 4A), eIF-4F (eukaryotic initiation factor 4F), 40S RP S3 (40S ribosomal protein S3), 60S RP L7 (60S ribosomal protein L7), 60S RP L18a (60S ribosomal protein L18a), and EF-1 $\alpha$ (elongation factor 1-alpha). Mtgapl (glyceraldehydes phosphate dehydrogenase gene). firmed by diagnostic RT-PCR to detect large subunit (LSU) ribosomal (r)RNA of $G$. mosseae which gave no signals in cDNA samples from control roots or root systems separated by a membrane from the fungus, while a PCR product was detected from roots at the appressoria stage (5 dai) and in mycorrhizal roots (10 dai) (Fig. 1E).

\section{Gene responses to $S$. meliloti.}

Expression of the 11 genes related to signal transduction, transcription, and translation was analyzed in $M$. truncatula 4 dai with $S$. meliloti in order to investigate possible common expression during early stages of the nodulation and mycorrhizal symbioses. A significant increase in transcripts was detected for only one gene corresponding to the SnRNP UA1 protein (Fig. 4). The expression of the other genes was not enhanced by inoculation of the bacteria, and expression of the nitrate reductase gene was significantly downregulated in the presence of S. meliloti (Fig. 4).

\section{DISCUSSION}

The lack of information concerning molecular interactions prior to and during initial cell-to-cell contact between AM fungi and host roots prompted the present investigation of gene responses to appressorium formation by $G$. mosseae at the root surface of $M$. truncatula. Among the 29 activated $M$. truncatula gene that are reported for the first time during these early events, 11 are related to signal transduction, transcription, and translation. Results indicate that these 11 genes form part of a molecular pathway which is associated with symbiosis establishment. This conclusion is inferred from the observation that expression of the corresponding genes is not enhanced when G. mosseae develops appressoria on roots of the $\mathrm{Myc}^{-} d m i 3$ mutant, where fungal development cannot proceed beyond the epidermis. Moreover, the signal transduction-related set of $M$. truncatula genes also are induced when roots of the wild-type genotype are separated from $G$. mosseae hyphae by a physical barrier, demonstrating that a diffusible fungal factor perceived by the host tissues is implicated. Similar observations on MtENOD11 activation by different AM fungi previously has led to the hypothesis of a putative Myc factor which could play an analogous role in AM signal mechanisms to Nod factors in

Table 2. Oligonucleotide primer sequences used in semi-quantitative reverse-transcription polymerase chain reaction analyses

\begin{tabular}{|c|c|c|c|}
\hline $\mathrm{MtGmEs}^{\mathrm{a}}$ & Similarity $^{\mathbf{b}}$ & Primer sequences & Number of cycles \\
\hline 330 & Annexin & $\begin{array}{l}\text { GAAGTCTCCGGTTGTGTGGT } \\
\text { GGACATCGAGCAATCAGGTT }\end{array}$ & 27 \\
\hline 9 & CLB1 protein & $\begin{array}{l}\text { GCTGCTGTCCATCGCTTGGATA } \\
\text { CGGCAGCTTTCAGTTTCTTC }\end{array}$ & 25 \\
\hline 133 & MAPK & $\begin{array}{l}\text { CAATGCAATTGCAAAG } \\
\text { GGCAGTGTCCTTTTTGGTGT }\end{array}$ & 27 \\
\hline 770 & NR & $\begin{array}{l}\text { CTTTAAACCCGCGTGAGAAA } \\
\text { TCATCTACGCTGCTTGTTGG }\end{array}$ & 27 \\
\hline 771 & SnRNP UA1 & $\begin{array}{l}\text { TGCAAGTAATGGTGGCTCAA } \\
\text { AAAGCATTTCGAGCATCCTG }\end{array}$ & 25 \\
\hline 768 & EIF-4A & $\begin{array}{l}\text { TTTGGAAGGAAAGGTGTTGC } \\
\text { AGTTCAGCAACATGGGAAGG }\end{array}$ & 27 \\
\hline 645 & EIF-4F & $\begin{array}{l}\text { CAAGCACCAGGGCACTATTC } \\
\text { CTGGAGGACGTGGACAATCT }\end{array}$ & 25 \\
\hline 12 & 40S RP S3 & $\begin{array}{l}\text { CATCCGGACAGCCTGTTAAG } \\
\text { CTCCTCCCTTTGGAGTGTGA }\end{array}$ & 27 \\
\hline 367 & 60S RP L7 & $\begin{array}{l}\text { TCCATCAGTTGGCTTCACAA } \\
\text { ATCGCAACAGGAGATTGACC }\end{array}$ & 27 \\
\hline 762 & 60S RP L18a & $\begin{array}{l}\text { CGTTTTGGCCAAGTATTGCT } \\
\text { TGATGCTGAATTTTGGTGGA }\end{array}$ & 27 \\
\hline 890 & EF-1 $1 \alpha$ & $\begin{array}{l}\text { TGGACATGTCGACTCTGGAA } \\
\text { TGTTCATCTCAGCAGCTTCCT }\end{array}$ & 22 \\
\hline
\end{tabular}

\footnotetext{
${ }^{\mathrm{a}} \mathrm{MtGmEs}=$ Medicago truncatula - Glomus mosseae early stage.

${ }^{\mathrm{b}} \mathrm{MAPK}=\mathrm{MAP}$ kinase, $\mathrm{NR}=$ nitrate reductase, $\mathrm{EIF}=$ eukaryotic initiation factor.
} 
the rhizobial symbiosis (Kosuta et al. 2003). In contrast to the MtENOD11 gene which is consistently activated by AM fungal molecules in roots of $\mathrm{Myc}^{-} d m i 1, d m i 2$, and $d m i 3$ mutants of M. truncatula (Kosuta et al. 2003), the diffusible factor from $G$. mosseae does not trigger activation of the signal transduction-related genes in the $d m i 3$ mutant. This is consistent with the specific sensing of a Myc factor by host roots and suggests that the $d m i 3$ gene is situated upstream in the cascade of events involved in perception of the fungal signal molecule or molecules.

Activation of two genes encoding a calcium lipid binding protein and an annexin during early $M$. truncatula J5-G. mosseae interactions could reflect the involvement of a calcium-modulated signaling pathway in the establishment of the AM symbiosis. This is further supposed from the similarity of $d m i 3$ to genes encoding calcium- and calmodulin-dependant protein kinases (Lévy et al. 2004; Mitra et al. 2004). Calcium is an intracellular messenger coordinating responses to numerous developmental cues and environmental challenges (White et al. 2003). Annexins belong to a family of calcium-binding proteins which are known to participate in a variety of $\mathrm{Ca}^{2+}$-regulated cellular processes (Morgan and Pilar Fernandez 1997). A member of the annexin family, MtAnnl, is induced by Nod factors during the early stages of nodulation, where it may play a role in cell cycle reactivation or cytoskeleton rearrangements during root-rhizobia interactions (Carvalho-Niebel et al. 2002). Moreover, it has been shown that calcium spiking is observed minutes after the addition of Nod factors, suggesting a role for $\mathrm{Ca}^{2+}$ as a secondary messenger in signal transduction of the Nod factor (Felle et al. 1999). In dmil, dmi2, and dmi3 mutants of $M$. truncatula, which are unable to establish nodule or mycorrhizal symbioses, the calcium spiking response to Nod factors is conserved only in plants mutated for the dmi3 gene, indicating that it is downstream of the other two genes in
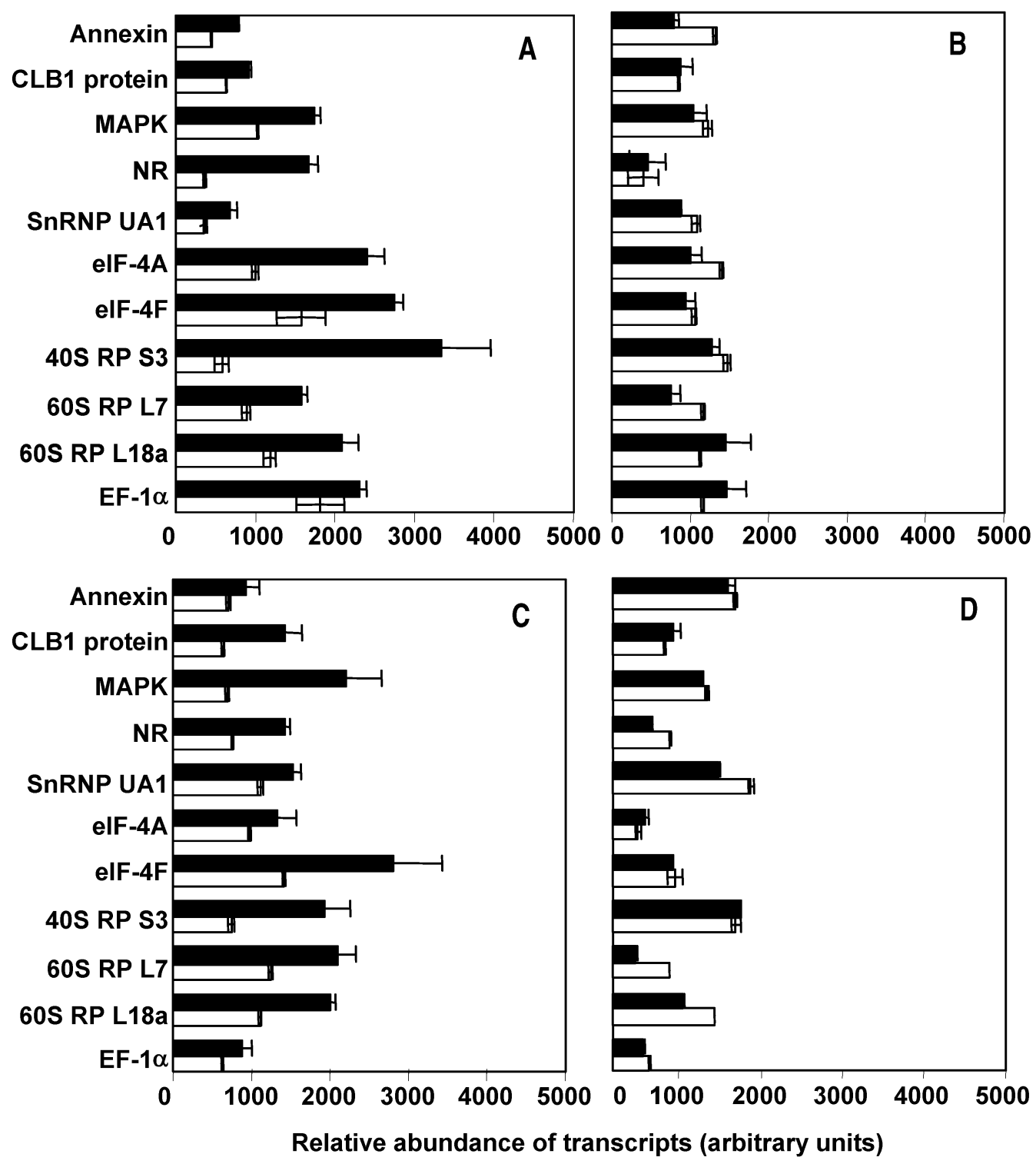

Fig. 3. Relative abundance of transcripts (semi-quantitative reverse-transcription polymerase chain reaction) of 11 Medicago truncatula genes. A, Glomus

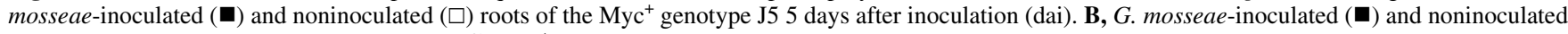
( $\square$ ) roots of the Myc $\mathrm{MRV}^{-} 5$ genotype 7 dai. $\mathbf{C}, \mathrm{Myc}^{+}$M. truncatula J5 grown 5 days in the presence ( $\square$ ) or absence ( $\square$ ) of germinated spores and hyphae of G. mosseae separated from roots by a nitrocellulose membrane. D, Myc ${ }^{-}$M. truncatula TRV25 grown 7 days in the presence (ロ) or absence ( $\square$ ) of germinated spores and hyphae of $G$. mosseae separated from roots by a nitrocellulose membrane. Bars represent standard errors of means. Signal transduction genes: Annexin, CLB1 protein $\left(\mathrm{Ca}^{2+}\right.$ lipid binding protein), MAPK (MAP kinase), NR (nitrate reductase); transcription gene: SnRNP UA1 (small nuclear ribonucleoprotein UA1); translation genes: eIF-4A (eukaryotic initiation factor 4A), eIF-4F (eukaryotic initiation factor 4F), 40S RP S3 (40S ribosomal protein S3), 60S RP L7 (60S ribosomal protein L7), 60S RP L18a (60S ribosomal protein L18a), and EF-1 $\alpha$ (elongation factor 1- $\alpha$ ). 
a signaling cascade (Catoira et al. 2000; Wais et al. 2000). The existence of mutants in $M$. truncatula and other legumes which are defective for nodulation and mycorrhization supposes common steps between the two root symbioses (Albrecht et al. 1999). However, Kosuta and associates (2003) provided evidence that the MtENOD11 gene responding to diffusible signals from both rhizobia and AM fungi is differentially regulated in the two symbioses and suggested that signal transduction in response to Nod and Myc factors occurs via different pathways. This hypothesis also is inferred from the present observations in that the signal transduction-related $M$. truncatula pathway elicited by $G$. mosseae is not activated in roots inoculated for 4 days by $S$. meliloti. Furthermore, the fact that the mycorrhizarelated signaling pathway is inactivated by mutation of the $d m i 3$ gene lends support to a role of the $d m i 3$ gene product in distinguishing the Myc factor from Nod factors, and in specific activation of the signal transduction pathway leading to mycorrhiza development.

The induction of a $M$. truncatula mitogen-activated protein (MAP) kinase gene by G. mosseae prior to and during appressorium formation on roots is consistent with the role of MAP kinases in the transduction of extracellular signals to intracellular targets in eukaryotes (Suzuki 2002). Distinct MAP kinase pathways are implicated in a wide variety of biological processes and, in plants, they are considered to play a role in signaling responses to abiotic stresses, pathogens, and plant hormones (Jonak et al. 1999). After translocation into the nucleus, they can activate sets of genes through phosphorylation of specific transcription factors. They have been well studied in defense reactions (Jonak et al. 1999; Zhang et al. 2001), and two MAP kinases involved in defense response and phosphorylating myelin basic protein on serine or threonine residues have been shown to be dependent on $\mathrm{Ca}^{2+}$ influx into cells (LebrunGarcia et al. 1998). The identity and the number of MAP

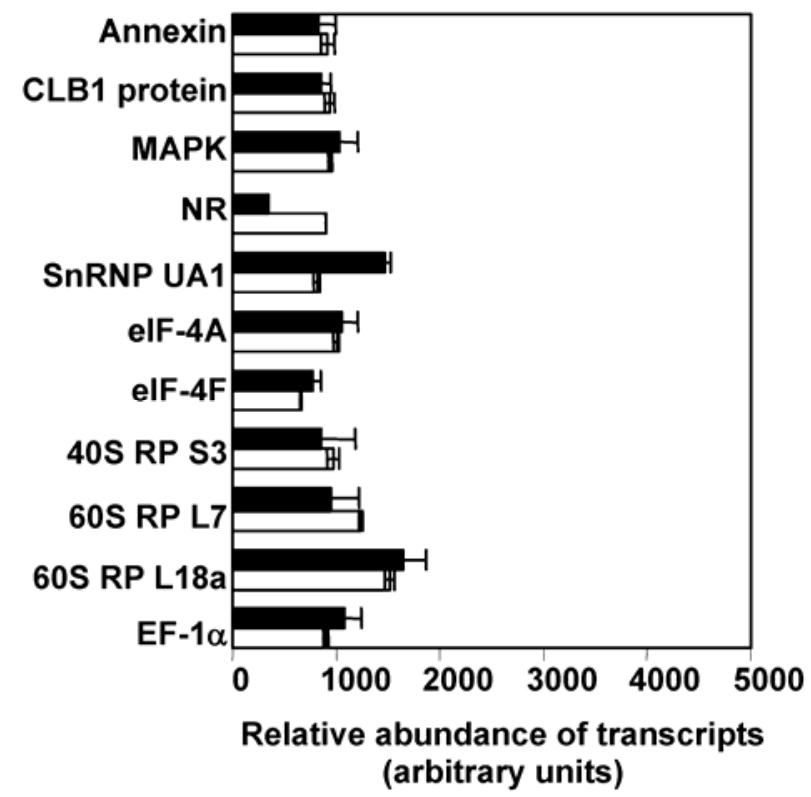

Fig 4. Relative abundance of transcripts (semi quantitative reversetranscription polymerase chain reaction) of 11 Medicago truncatula genes from Sinorhizobium meliloti-inoculated (ם) and noninoculated ( $\square$ ) roots of the $\mathrm{Myc}^{+}$genotype J5 4 days after inoculation. Bars represent standard errors of means. Signal transduction genes: Annexin, CLB1 protein $\left(\mathrm{Ca}^{2+}\right.$ lipid binding protein), MAPK (MAP kinase), NR (nitrate reductase); transcription gene: SnRNP UA1 (small nuclear ribonucleoprotein UA1); translation genes: eIF-4A (eukaryotic initiation factor 4A), eIF-4F (eukaryotic initiation factor 4F), 40S RP S3 (40S ribosomal protein S3), 60S RP L7 (60S ribosomal protein L7), 60S RP L18a (60S ribosomal protein L18a), and EF-1 $\alpha$ (elongation factor 1- $\alpha$ ). kinases, their sustained activation, and their regulation in general may be determinant points directing downstream events in signal transduction pathways (Lebrun-Garcia et al. 1998). This may be relevant to arbuscular mycorrhiza interactions because two other MAP kinases, showing no homology to the gene reported here, have been reported to be upregulated during early root colonization events by Glomus versiforme (Karsten) Berch in M. truncatula (Liu et al. 2003).

Although nitrate reductase is a key enzyme of nitrate assimilation in higher plants through its conversion of nitrate to nitrite, it also is implicated in the generation of NO from nitrite (Neill et al. 2003). The nitrate reductase gene of M. truncatula is activated before symbiosis establishment by $G$. mosseae; therefore, it may be related to this second function in the early root-fungal interactions. $\mathrm{NO}$, which is recognized to be a widespread signaling molecule in mammal cells, is now considered as an endogenous maturation- and senescence-regulating factor in higher plants (Wendehenne et al. 2001). It is associated with several physiological responses in plants, including plant defense responses, programmed cell death, stomatal closure, or root growth. The mobile nature of $\mathrm{NO}$ and its chemical reactivity with various cell targets make it a potentially important molecule in cell responses. The downstream effects of NO may be induced directly by its interactions with, for example, ion channel proteins or proteins that regulate gene expression, or indirectly by interactions with signaling proteins such as protein kinases or with secondary messenger-generative enzymes (Neill et al. 2003). NO appears to act through cGMP and cADPR to activate intracellular $\mathrm{Ca}^{2+}$-permeable channels, and also plays a role in elevating free cytosolic $\mathrm{Ca}^{2+}$ (Wendehenne et al. 2004). This is particularly relevant in relation to the fact that DMI3 encodes a $\mathrm{Ca}^{2+}$ - and calmodulin-dependent protein kinase in $M$. truncatula.

The concomitant activation by G. mosseae in M. truncatula J5 roots of a small nuclear ribonucleoprotein UA1 gene with a role in mRNA splicing is suggestive of enhanced transcriptional activity. The induction of ribosomal genes along with initiation and elongation factors is coherent with subsequent translational events leading to de novo protein synthesis and cell activation in $\mathrm{Myc}^{+}$roots responding to AM fungal signals. The fact that none of these genes respond to appressorium development in the $\mathrm{Myc}^{-}$genotype supports the hypothesis that they are active in transcription and translation events downstream of those associated with the signal transduction pathway or pathways elicited by $G$. mosseae. Cell activation by appressorium development on $\mathrm{Myc}^{+}$roots is seen in the other ESTs identified in the SSH library and in coding for proteins involved in cell cycle machinery (cyclin B), lipid metabolism (diacylglycerol acylCoA acyltransferase and isopentenyl diphosphate isomerase), or cell wall properties (extensin and expansin).

In conclusion, most studies in the past have focused on genes related to the arbuscular stage of mycorrhizal interactions. In the present study, we have provided evidence that a signal transduction and translation pathway leading to the establishment of the mycorrhizal symbiosis is activated in roots by AM fungal molecules, and that plant gene activation occurs without contact between the symbionts. The lack of activation of this molecular pathway by $S$. meliloti points to cell processes which discriminate at an early point between mycorrhizal and nodulating root symbionts. The identification of signal transduction-related plant genes responding to AM fungal molecules opens new perspectives for deciphering the molecular dialogue which is involved in the recognition process necessary for symbiosis establishment, and for pinpointing receptors at the host cell surface which specifically sense the AM fungal signals. 


\section{MATERIALS AND METHODS}

Plant growth and inoculation.

Seed of M. truncatula Gaertn. cv. Jemalong, line J5, and the $\mathrm{Myc}^{-} d m i 3$ mutant TRV25 (provided by G. Duc, INRA-Dijon, France) were surface sterilized for $6 \mathrm{~min}$ in $98 \%$ sulphuric acid, $5 \mathrm{~min}$ in $96 \%$ ethanol, an $10 \mathrm{~min}$ in $3 \%$ calcium hypochlorite, then rinsed in sterile distilled water. They were germinated for $48 \mathrm{~h}$ on $0.7 \%$ Bactoagar (Difco Laboratories, Detroit) at $25^{\circ} \mathrm{C}$ in the dark and transplanted into a 75-ml sterilized (autoclaved twice at $120^{\circ} \mathrm{C}$ ) mixture of Terragreen (OilDri-US special, Mettman, Germany) and a neutral clay soil (2:1) for noninoculated plants, or in a $75-\mathrm{ml}$ mixture $(2: 1)$ of Terragreen and a soilbased inoculum (spores, roots, and hyphae) of G. mosseae Nicol \& Gerd., isolate BEG 12, for inoculated plants. Inoculum was prior checked for absence of $S$. meliloti by growing it for 3 weeks with the hypernodulating $M$. truncatula genotype TR122. Control plants received filtered washings (Whatman no. 2; Whatman International, Ltd., Maidstone, England) of $G$. mosseae inoculum to reconstitute associated microflora. Plants were grown under constant conditions: $70 \%$ relative humidity, 16-h photoperiod, night and day temperatures of 19 and $22^{\circ} \mathrm{C}$, respectively, $360 \mu \mathrm{mol} \mathrm{m} \mathrm{m}^{-2} \mathrm{~s}^{-1}$ (LI-189 LI-COR radiation sensors; LI-Cor, Lincoln, NB, U.S.A.), and received $5 \mathrm{ml}$ of Long Ashton solution without phosphate weekly (Hewitt 1966). Plants were harvested 5 or 10 dai for the J5 genotype and 7 dai after inoculation for the TRV25 mutant. Fresh shoot and root weights were recorded and roots were stored immediately in liquid nitrogen. Root systems of three plants per experiment were digested for $48 \mathrm{~h}$ in $10 \% \mathrm{KOH}$ at room temperature and stained overnight with $0.05 \%$ trypan blue in glycerol, to estimate the number of appressoria on roots and evaluate mycorrhiza colonization according to the MYCOCALC program.

In order to determine whether physical contact between the symbionts was necessary for gene expression, the following biological system was developed. Spores of $G$. mosseae were surface sterilized for $15 \mathrm{~min}$ in a solution of chloramine $\mathrm{T}(2 \%)$, streptomycin $(0.02 \%)$, gentamycin $(0.01 \%)$, and Tween 20 (1 drop $\left.100 \mu^{-1}\right)$, then germinated for 15 days between sterile membranes of nitrocellulose (Schleicher and Schuell, Dassel, Germany) in autoclaved moist quartz sand. The sandwich of germinated spores was placed over 3-cm-long root systems of 2day-old $M$. truncatula seedlings held between sterile nitrocellulose membranes in petri dishes $(9 \mathrm{~cm}$ in diameter) containing the autoclaved Terragreen/soil (2:1) mix. Root systems of control plants were covered with an empty membrane sandwich. Plants were grown in the same conditions as above for 5 (J5 genotype) or 7 (dmi3 mutant TRV25) days. Spore germination and hyphal growth was verified microscopically on all membranes at plant harvest after staining in a drop of $0.1 \%$ methyl blue in $50 \%$ lactic acid. Random samples of three seedlings were stained with trypan blue as described above, in order to verify the absence of contact between the symbionts.

In order to compare expression related to mycorrhizal and nodulation interactions, rhizobacteria were introduced into the substrate as a suspension in Long Ashton solution without nitrogen containing $10^{6} \mathrm{CFU} \mathrm{m} \mathrm{m}^{-1}$ of S. meliloti strain RCR 2011. Control plants received only Long Ashton solution. Plants were harvested for each treatment 4 dai and immediately stored in liquid nitrogen. Root colonization by the bacteria was evaluated from a sample of five plants after plating serial dilutions of rhizoplane suspensions on King B agar (King et al. 1954), as described by Sanchez and associates (2004).

\section{RNA extraction for SSH library construction.}

Noninoculated or G. mosseae-inoculated M. truncatula roots were extracted according to the method of Franken and
Gnädinger (1994). Frozen roots were ground to a fine powder in liquid nitrogen and transferred to NTES buffer $(50 \mathrm{mM}$ Tris HCL, pH 9, 5 mM EDTA, $150 \mathrm{mM} \mathrm{NaCl}, 5 \%$ sodium dodecyl sulfate (SDS), and $1 / 100 \mathrm{vol}$ of $\beta$-mercaptoethanol). Nucleic acids were separated from proteins by three sequential extractions in $1 \mathrm{vol}$ of phenol ( $\mathrm{pH} 4.5-5) /$ chloroform/isoamyl alcohol $(25 / 24 / 1)$ and one in chloroform (1 vol). The RNA in the aqueous phase was purified by precipitation overnight at $-20^{\circ} \mathrm{C}$ in $0.05 \mathrm{vol}$ of $1 \mathrm{M}$ acetic acid and $0.7 \mathrm{vol}$ of $95 \%$ ethanol, $4 \mathrm{~h}$ at $4^{\circ} \mathrm{C}$ in 1 vol of $4 \mathrm{M}$ lithium chloride, and overnight at $-20^{\circ} \mathrm{C}$ in $0.1 \mathrm{vol}$ of $3 \mathrm{M}$ sodium acetate and $2.5 \mathrm{vol}$ of $95 \%$ ethanol. All RNA solutions were prepared with diethyl pyrocarbonate (DEPC) water (Sigma, Saint Quentin-Fallavier, France). The final RNA pellets were washed with $75 \%$ ethanol and were resuspended in $50 \mu \mathrm{l}$ of DEPC water per $0.5 \mathrm{~g}$ of root. RNA in the aqueous phase was treated with DNase for $30 \mathrm{~min}$ at $37^{\circ} \mathrm{C}$ ( $25 \mu \mathrm{g}$ of total RNA, $40 \mathrm{U}$ of RNase inhibitor, $3 \mathrm{U}$ of RNasefree DNase, $6 \mu \mathrm{l}$ of $10 \times$ buffer, and DEPC water to $60 \mu \mathrm{l}$ ). DNase was removed by phenol/chloroform/isoamyl alcohol $(25 / 24 / 1)$, and RNA was precipitated overnight at $-20^{\circ} \mathrm{C}(1 / 10$ vol of $3 \mathrm{M}$ sodium acetate, $2.5 \mathrm{vol}$ of $95 \%$ ethanol) and resuspended in DEPC water. RNA quantity and quality were estimated by measuring the absorbance at 260 and $280 \mathrm{~nm}$ and by $1 \%$ denaturating gel electrophoresis.

\section{SSH cDNA-library.}

The SSH library was constructed using the PCR Select system according to the protocol provided by the supplier (Clontech Laboratories, Palo Alto, CA, U.S.A.). Briefly, $2 \mu \mathrm{g}$ of mRNA from 5-day-old G. mosseae-inoculated (four appressoria per $\mathrm{cm}$ of root) and noninoculated roots were used as template to synthesize two cDNA populations which then were digested with the RsaI restriction enzyme. Two different adaptors carrying PCR and cloning sites were ligated to the cDNA from inoculated roots in order to obtain two populations of tester cDNA. No adaptors were added to noninoculated root cDNA (driver cDNA). After verification of the ligation efficiency, each tester cDNA was subtracted by hybridizing it to half of the driver cDNA, followed by a second hybridization of the two subtracted tester cDNA samples. Thereafter, cDNA fragments corresponding to differentially expressed transcripts from the inoculated root cDNA were amplified and cloned into the pGEM-T vector (Promega France, Charbonnière-les-Bains, France).

In order to check subtraction efficiency of DNA samples, expression of the gapdh gene of $M$. truncatula (encoding a glyceraldehyde phosphate dehydrogenase) was evaluated using a 1:10 dilution of the subtracted and nonsubtracted cDNA samples as template and Gapfor (TGA GGT TGG AGC TGA TTA CG) and Gaprev (AGC CTT GGC AGC TCC AGT GC) primers designed on the consensus sequence of the Mtgapl cluster MtC00030_GC. PCR was carried out in a 20- $\mu$ l final volume containing $2.5 \mathrm{mM} \mathrm{MgCl}, 125 \mu \mathrm{M}$ dNTP, $0.5 \mu \mathrm{M}$ each primer, $0.5 \mathrm{U}$ of $\mathrm{Taq}$ polymerase (Qbiogene, Illkirch, France), and $1 \times$ buffer provided by the supplier of the enzyme. After an initial denaturation of $5^{\prime}$ at $95^{\circ} \mathrm{C}, 10,12,15$, or 17 amplification cycles were performed for $45 \mathrm{~s}$ at each temperature step (denaturing, $94^{\circ} \mathrm{C}$; annealing, $55^{\circ} \mathrm{C}$; and elongation, $72^{\circ} \mathrm{C}$ ), with a final extension step of $5 \mathrm{~min}$ at $72^{\circ} \mathrm{C}$. RT-PCR analysis with specific Mtgapl primers gave an amplification product at 15 cycles for the nonsubtracted sample and a weaker signal at 17 cycles for the subtracted sample, showing that the subtraction had been efficient.

\section{Reverse Northern hybridization of cDNA arrays and EST sequencing.}

PCR reactions were conducted on ESTs from the SSH library in a $50-\mu$ l reaction volume containing $1 \mu \mathrm{l}$ of $1: 100$ 
cDNA clone in water, $0.5 \mathrm{U}$ of Taq polymerase (Qbiogene), $125 \mu \mathrm{M}$ dNTP, and $0.5 \mu \mathrm{M}$ each primer (18.1for GTCACGACGTTGTAAAACG and 18.2rev AGCTATGACCA TGATTACG). Amplifications consisted of an initial denaturetion step for $1 \mathrm{~min}$ at $95^{\circ} \mathrm{C} ; 30$ cycles with annealing for $1 \mathrm{~min}$ at $56^{\circ} \mathrm{C}$ and $1 \mathrm{~min} 30$ at $72^{\circ} \mathrm{C}$; and a final extension for $5 \mathrm{~min}$ at $72^{\circ} \mathrm{C}$. PCR products were separated on $1.2 \%$ agarose gels, transferred to Hybond-XL (Amersham Bioscience, Orsay, France) by capillary blotting, and fixed under UV light $(70,000 \mathrm{~J}$ $\mathrm{cm}^{-2}$ ).

cDNA, synthesized from $2.5 \mu \mathrm{g}$ of total RNA, was ${ }^{32} \mathrm{P}-$ labeled by RT-PCR and purified on ProbeQuant G-50 Micro Columns (Amersham Bioscience) before denaturing for $5 \mathrm{~min}$ at $95^{\circ} \mathrm{C}$. Membranes were prehybridized for $1 \mathrm{~h}$ at $60^{\circ} \mathrm{C}$ and hybridized with probes overnight at $60^{\circ} \mathrm{C}$ in Church buffer (Church and Gilbert 1984), then washed twice for $5 \mathrm{~min}$ in $2 \times$ SSC ( $1 \times$ SSC is $0.15 \mathrm{M} \mathrm{NaCl}$ plus $0.015 \mathrm{M}$ sodium citrate)/ $0.1 \% \mathrm{SDS}$ at room temperature, twice for $20 \mathrm{~min}$ in $0.5 \times$ $\mathrm{SSC} / 0.1 \% \mathrm{SDS}$ at $60^{\circ} \mathrm{C}$, and twice for $20 \mathrm{~min}$ in $0.5 \times \mathrm{SSC} /$ $0.1 \%$ SDS at $65^{\circ} \mathrm{C}$. Hybridization signals were quantified in a Storm 860 phosphorimager with ImageQuant software (Molecular Dynamics, Amersham Bioscience) and normalized using the Mtgapl gene.

ESTs corresponding to genes showing more than 2.5-fold expression in $G$. mosseae-inoculated roots were sequenced using T7 and SP6 primers (MWG-Biotech, Ebersberg, Germany). Sequences of cDNA were compared using blastn and blastx algorithms with sequences in the TIGR $M$. truncatula gene index database to identify similarities at nucleic and amino acids levels.

\section{Semi-quantitative RT-PCR.}

Total RNA was isolated using the RNA easy Plant Mini kit (Qiagen, Courtaboeuf, France) according to the manufacturer's instructions. cDNA was prepared from $2 \mu \mathrm{g}$ of total RNA added to $1.5 \mu \mathrm{g}$ of oligodT ${ }_{15}$ dNTPs $(2.5 \mathrm{mM}$ each) and made up to a final volume of $11.5 \mu \mathrm{l}$ with sterile distilled water. RNA was denatured for $5 \mathrm{~min}$ at $70^{\circ} \mathrm{C}$, placed on ice, and $5 \mu \mathrm{l}$ of MMLV 5x reaction buffer, $300 \mathrm{U}$ of MMLV reverse transcriptase, and $80 \mathrm{U}$ of RNase inhibitor were added. Firststrand cDNA was synthesized at $25^{\circ} \mathrm{C}$ for $15 \mathrm{~min}$ followed by $50 \mathrm{~min}$ at $42^{\circ} \mathrm{C}$ and $2 \mathrm{~min}$ at $96^{\circ} \mathrm{C}$. Semi quantitative RT-PCR was performed according to Taylor and Harrier (2003). Genespecific fragments were amplified by PCR using primers deduced from EST sequences at $95^{\circ} \mathrm{C}$ for $5 \mathrm{~min}, 93^{\circ} \mathrm{C}$ for $45 \mathrm{~s}$, annealing for $60^{\circ} \mathrm{C}$ for $45 \mathrm{~s}, 72^{\circ} \mathrm{C}$ for $1 \mathrm{~min}$, and a final extension at $72^{\circ} \mathrm{C}$ for $5 \mathrm{~min}$. Amplification products were analyzed by $1.2 \%$ agarose gel electrophoresis, stained by ethidium bromide, and quantified in a Storm 860 phosphorimager with ImageQuant software (Molecular Dynamics, Amersham Bioscience).

To further verify that $G$. mosseae had not come into contact with M. truncatula when germinated spores were separated from root systems by a nitrocellulose membrane, PCR was performed to detect fungal cDNA in roots separated from the fungus and compared with roots directly inoculated at 5 and 10 dai. Specific primers of the LSU rRNA of $G$. mosseae were used: 5.25 (ATCAACCTTTTGAGCTCG) (van Tuinen et al. 1998) and FLR2 (GTCGTTTAAAGCCATTACGT) (Trouvelot et al. 1999). PCR conditions were $94^{\circ} \mathrm{C}$ for $5 \mathrm{~min} ; 30$ cycles of $92^{\circ} \mathrm{C}$ for $45 \mathrm{~s}$, annealing for $60^{\circ} \mathrm{C}$ for $45 \mathrm{~s}$, and elongation at $72^{\circ} \mathrm{C}$ for $1 \mathrm{~min}$; with a final elongation of $1 \mathrm{~min}$ at $72^{\circ} \mathrm{C}$. PCR products were observed by $1.4 \%$ agarose gel electrophoresis after staining with ethidium bromide.

Transcripts of the Mtgapl gene were used to verify equivalent RT to cDNA and equivalent amplification in PCR. Expression levels were checked by semi-quantitative PCR of tran- scripts on cDNA synthesized from RNA of $M$. truncatula roots inoculated or not with $G$. mosseae or $S$. meliloti as described above. PCR was performed on RT products diluted to 1:40 using the Gapfor and Gaprev primers and amplification products were quantified as described above.

\section{Statistical analyses.}

Data for plant growth were analyzed with SYSTAT software. Data from semi-quantitative PCR evaluations of gene expression in replicate RNA batches of noninoculated and $G$. mosseae- or $S$. meliloti-inoculated roots from three independent inoculation experiments were compared using the Student $t$ test.

\section{ACKNOWLEDGMENTS}

This project was supported by the EU project MEDICAGO (QLG2-CT2000-00676) and an INRA Action Transversale Structurante (AIP P00241). We thank C. Arnould for technical assistance; N. Amiour, G. Aubert, D. van Tuinen, and A. Gollotte for helpful discussion; V. Monfort for providing inoculum of Glomus mosseae; G. Duc for providing Medicago truncatula seed; and A. Hartmann for providing the Sinorhizobium meliloti strain.

\section{LITERATURE CITED}

Albrecht, C., Geurts, R., and Bisseling, T. 1999. Legume nodulation and mycorrhizae formation; Two extremes in host specificity meet. EMBO (Eur. Mol. Biol. Organ.) J. 18:281-288.

Ané, J. M., Kiss, G. B., Riely, B. K., Penmetsa, R. V., Oldroyd, G. E., Ayax, C., Lévy, J., Debelle, F., Baek, J. M., Kalo, P., Rosenberg, C., Roe, B. A., Long, S. R., Dénarié, J., and Cook, D. R. 2004. Medicago truncatula DMI1 required for bacterial and fungal symbioses in legumes. Science. 10.1126/science.1092986. Online publication.

Barea, J. M., Gryndler, M., Lemanceau, P., Schüepp, H., and Azcon, R. 2002. The rhizosphere of mycorrhizal plants. Pages 1-18 in: Mycorrhizal Technology in Agriculture: From Genes to Bioproducts. S. Gianinazzi, H. Schüepp, J. M. Barea, and K. Haselwandter, eds. Birkäuser Verlag, Basel.

Blilou, I., Bueno, P., Ocampo, J. A., and Garcia-Garrido, J. M. 2000. Induction of catalase and ascorbate peroxidase activities in tobacco roots inoculated with the arbuscular mycorrhizal Glomus mosseae. Mycol. Res. 104:722-725.

Bonanomi, A., Oetiker, J. H., Guggenheim, R., Boller, T., Wiemken, A., and Vögeli-Lange, R. 2001. Arbuscular mycorrhiza in mini-mycorrhizotrons: First contact of Medicago truncatula roots with Glomus intraradices induces chalcone synthase. New Phytol. 150:573-582.

Brechenmacher, L. 2003. Investigation of the functional genome involved in the endomycorrhizal symbiosis in barrel medic (Medicago truncatula). European Doctoral Thesis, Burgundy University, France.

Brechenmacher, L., Weidmann, S., van Tuinen, D., Chatagnier, O., Gianinazzi, S., Franken, P., and Gianinazzi-Pearson, V. 2004. Expression profiling of up-regulated plant and fungal genes in early and late stages of Medicago truncatula/Glomus mosseae interactions. Mycorrhiza /101007/s00572-003-0263-4. Online publication.

Burleigh, S. 2001. Relative quantitative RT-PCR to study the expression of plant nutrient transporters in arbuscular mycorrhizas. Plant Sci. 160:899-904.

Calantzis, C., Morandi, D., Arnould, C., and Gianinazzi-Pearson, V. 2001. Cellular interactions between $G$. mosseae and a $\mathrm{Myc}^{-}$mutant in Medicago truncatula. Symbiosis 30:97-108.

Carvalho-Niebel, F., Timmers, A. C. J., Chabaud, M., Defaux-Petras, A., and Barker, D. G. 2002. The Nod factor-elicited annexin MtAnnl is preferentially localised at the nuclear periphery in symbiotically activated root tissues of Medicago truncatula. Plant J. 32:343-352.

Catoira, R., Galera, C., de Billy, F., Penmetsa, R. V., Journet, E. P., Maillet, F., Rosenberg, C., Cook, D., Gough, C., and Dénarié, J. 2000. Four genes of Medicago truncatula controlling components of a Nod factor transduction pathway. Plant Cell 12:1647-1665.

Chabaud, M., Venard, C., Defaux-Petras, A., Bécard, G., and Barker, D. G. 2002. Targeted inoculation of Medicago truncatula in vitro root cultures reveals MtENOD11 expression during early stages of infection by arbuscular mycorrhizal fungi. New Phytol. 156:265-273.

Church, G., and Gilbert, W. 1984. Genomic sequencing. Proc. Nat. Acad. Sci. U.S.A. 81:1991-1995.

Duc, G., Trouvelot, A., Gianinazzi-Pearson, V., and Gianinazzi, S. 1989. 
First report of non-mycorrhizal plants mutants $\left(\mathrm{Myc}^{-}\right)$obtained in pea (Pisum sativum L.) and fababean (Vicia faba L.). Plant Sci. 60:215-222.

Endre, G., Kereszt, A., Kevei, Z., Mihacea, S., Kalo, P., and Kiss, G. B. 2002. A receptor kinase gene regulating symbiotic nodule development. Nature 417:962-966.

Felle, H. H., Kondorosi, E., Kondorosi, A., and Schultze, M. 1999. Elevation of cytosolic free $\left[\mathrm{Ca}^{2+}\right]$ is indispensable for the transduction of the Nod factor signal in alfalfa. Plant Physiol. 121:273-280.

Franken, P., and Gnädinger, F. 1994. Analysis of parsley arbuscular endomycorrhiza: Infection development and mRNA levels of defense-related genes. Mol. Plant-Microbe Interact. 7:612-620.

Gianinazzi-Pearson, V. 1996. Plant cell responses to arbuscular mycorrhizal fungi: Getting to the roots of the symbiosis. Plant Cell 8:1871-1883.

Giovannetti, M., Sbrana, C., and Logi, C. 1994. Early processes involved in host recognition by arbuscular mycorrhizal fungi. New Phytol. 127:703-709.

Harrison, M. J. 1999. Molecular and cellular aspects of the arbuscular mycorrhizal symbiosis. Annu. Rev. Plant Physiol. Plant Mol. Biol. 50:361389

Hewitt, E J. 1966. Sand and Water Culture Methods Used in Studies of Plant Nutrition. Commonwealth Agricultural Bureau, London.

Jonak, C., Ligterink, W., and Hirt, H. 1999. MAP kinases in plant signal transduction. Cell. Mol. Life Sci. 55:204-213.

King, E., Ward, M., and Raney, D. 1954. Two simple media for the demonstration of pyocianin and fluorescein. J. Lab. Clin. Med. 44:301-307.

Kosuta, S., Chabaud, M., Lougnon, G., Gough, C., Dénarié, J., Barker D. G., and Bécard, G. 2003. A diffusible factor from arbuscular mycorrhizal fungi induces symbiosis-specific MtENOD11 expression in roots of Medicago truncatula. Plant Physiol. 131:952-962.

Lebrun-Garcia, A., Ouaked, F., Chiltz, A., and Pugin, A. 1998. Activation of MAPK homologues by elicitors in tobacco cells. Plant J. 15:773-781.

Lévy, J., Bres, C., Geurts, R., Chalhoub, B., Kulikova, O., Duc, G., Journet, E. P., Ané, J. M., Laubert, E., Bisseling, T., Dénarié, J., Rosenberg, C. and Debellé, F. 2004. A putative $\mathrm{Ca}^{2+}$ and calmodulin-dependant protein kinase required for bacterial and fungal symbioses. Science 10.1126/science.1093038. Online publication

Liu, J., Blaylock, L., Endre, G., Cho, J., Town, C. D., Vandenbosch, K. A., and Harrison, M. J. 2003. Transcript profiling coupled with spatial expression analyses reveals genes involved in distinct developmental stages of an arbuscular mycorrhizal symbiosis. Plant Cell 15:2106-2123.

Mitra, R. M., Gleason, C. A., Edwards, A., Hadfield, J., Downie, J. A., Oldroyd, G. E. D., and Long, S. R. 2004. A Ca ${ }^{2+} /$ calmodulin-dependant protein kinase required for symbiotic nodule development: Gene identification by transcript-based cloning. Proc. Natl. Acad. Sci. U.S.A. 101:4701-4705.

Morgan, R., and Pilar Fernandez, M. 1997. Distinct annexin subfamilies in plants and protists diverged prior to animal annexins and from a common ancestor. J. Mol. Evol. 44:178-188.

Nagahashi, G. N., and Douds, D. D. 1997. Appressorium formation by AM fungi on isolated cell walls of carrot roots. New Phytol. 136:299 304

Neill, S. J., Desikan, R., and Hancock, J. T. 2003. Nitric oxide signaling in plants. New Phytol. 159:11-35.

Requena, N., Breuninger, M., Franken, P., and Ocon, A. 2003. Symbiotic status, phosphate and sucrose regulate the expression of two plasma membrane $\mathrm{H}^{+}$-ATPase genes from the mycorrhizal fungus Glomus mosseae. Plant Physiol. 132:1540-1549.

Requena, N., Mann, P., Hampp, R., and Franken, P. 2002. Early developmentally regulated genes in the arbuscular mycorrhizal fungus Glomus mosseae: Identification of GmGIN1, a novel gene with homology to the C-terminus of metazoan hedgehog proteins. Plant Soil 244:129-139.

Ruiz-Lozano, J. M., Roussel, H., Gianinazzi, S., and Gianinazzi-Pearson, V. 1999. Defense genes are differentially induced by a mycorrhizal fungus and Rhizobium sp. in wild-type and symbiosis-defective pea genotypes. Mol. Plant-Microbe Interact. 12:976-984.
Sagan, M., Morandi, D., Tarenghi, E., and Duc, G. 1995. Selection of nodulation and mycorrhizal mutants in the model plant Medicago truncatula (Gaertn) after gamma-ray mutagenesis. Plant Sci. 111:63-71.

Sanchez, L., Weidmann, S., Brechenmacher, L., Batoux, M., van Tuinen, D., Lemanceau, P., Gianinazzi, S., and Gianinazzi-Pearson, V. 2004. Common gene expression in Medicago truncatula roots in response to Pseudomonas fluorescens colonization, mycorrhiza development and nodulation. New Phytol. 161:855-863.

Schüssler, A., Schwarzott, D., and Walker, C. 2001. A new fungal phylum, the Glomeromycota: Phylogeny and evolution. Mycol. Res. 105:14131421.

Stracke, S., Kistner, C., Yoshida, S., Mulder, L., Sato, S., Kaneko, T., Tabata, S., Sandal, N., Stougaard, J., Szczyglowski, K., and Parniske, M. 2002. A plant receptor-like kinase required for both bacterial and fungal symbiosis. Nature 417:959-962.

Suzuki, K. 2002. MAP kinase cascade in elicitor signal transduction. J. Plant Res. 115:237-244.

Tamasloukht, B., Séjalon-Delmas, N., Kluever A., Jauneau, A., Roux, C., Bécard, G., and Franken, P. 2003. Root factors induce mitochondrialrelated gene expression and fungal respiration during the developmental switch from a symbiosis to presymbiosis in the arbuscular mycorrhizal fungus Gigaspora rosea. Plant Physiol. 131:1468-1478.

Taylor, J., and Harrier, L. 2003. Expression studies of plant genes differentially expressed in leaf and root tissues of tomato colonised by the arbuscular mycorrhizal fungus Glomus mosseae. Plant Mol. Biol. 51:619629.

Trouvelot, S., van Tuinen, D., Hijri, M., and Gianinazzi-Pearson, V. 1999. Visualization of ribosomal DNA loci in spore interphasic nuclei of glomalean fungi by fluorescence in situ hybridization. Mycorrhiza 8:203206.

van Tuinen, D., Jacquot, E., Zaho, B., Gollotte, A., and Gianinazzi-Pearson, V. 1998. Characterization of root colonization profiles by a microcosm community of arbuscular mycorrhizal fungi using 25S rDNA-targeted nested PCR. Mol. Ecol. 7:879-887.

Wais R. J., Galera, C., Oldroyd, G., Catoira, R., Penmetsa, R V., Cook, D., Gough, C., Dénarié, J., and Long, S. R. 2000. Genetic analysis of calcium spiking responses in nodulation mutants of Medicago truncatula. Proc .Natl. Acad. Sci. U.S.A. 97:13407-13412.

Walker, C. M., and Trappe, J. M. 1993. Names and epithets in Glomales and Endogonales. Mycol. Res. 97:339-444.

Wegel, E., Schauser, L., Sandal, N., Stougaard, J., and Parniske, M. 1998. Mycorrhiza mutants of Lotus japonicus define genetically independent steps during symbiotic infection. Mol. Plant-Microbe Interact. 11:933936.

Wendehenne, D., Pugin, A., Klessig, D. F., and Durner, J. 2001. Nitric oxide: Comparative synthesis and signaling in animal and plant cells. Trends Plant Sci. 6:177-183.

Wendehenne, D., Durner, J., and Klessig, F. F. 2004. Nitric oxide: A new player in plant signaling and defence responses. Curr. Opin. Plant Biol 7:1-7.

White, P., Broadley, M., and Martin, R. 2003. Calcium in plants. Ann. Bot. 93:487-511.

Zhang, S., and Klessig, D. 2001. MAPK cascades in plant defense signaling. Trends Plant Sci. 6:520-527.

\section{AUTHOR-RECOMMENDED INTERNET RESOURCES}

Institut National de la Recherche Agronomique (INRA) MYCOCALC program:

www.dijon.inra.fr/bbceipm/Mychintec/mycocalc-prg/download.html

The Institute for Genomic Research (TIGR) M. truncatula gene index: www.tigr.org/tdb/tgi/ntgi

Medicago EST navigation system (MENS) website: medicago.toulouse.inra.fr/Mt/EST/ 